Review of Income and Wealth

Series 55, Number 3, September 2009

\title{
INTANGIBLE CAPITAL AND U.S. ECONOMIC GROWTH
}

\author{
by Carol Corrado* \\ The Conference Board, New York \\ Charles Hulten \\ University of Maryland and NBER \\ AND \\ DANIEL SiCHEL \\ Federal Reserve Board, Washington DC
}

Published macroeconomic data traditionally exclude most intangible investment from measured GDP. This situation is beginning to change, but our estimates suggest that as much as $\$ 800$ billion is still excluded from U.S. published data (as of 2003), and that this leads to the exclusion of more than $\$ 3$ trillion of business intangible capital stock. To assess the importance of this omission, we add intangible capital to the standard sources-of-growth framework used by the BLS, and find that the inclusion of our list of intangible assets makes a significant difference in the observed patterns of U.S. economic growth. The rate of change of output per worker increases more rapidly when intangibles are counted as capital, and capital deepening becomes the unambiguously dominant source of growth in labor productivity. The role of multifactor productivity is correspondingly diminished, and labor's income share is found to have decreased significantly over the last 50 years.

\section{INTRODUCTION AND BACKGROUND}

The revolution in information technology is apparent in the profusion of new products available in the marketplace (goods with the acronyms PCs, PDAs, ATMs, wi-fi), as well as items like the internet, cell phones, and e-mail. These innovations are part of a broader technological revolution based on the discovery of the semiconductor, often called the "IT revolution." However, while its effects are apparent in the marketplace, its manifestation in the macroeconomic statistics on growth has been slow to materialize. Writing in 1987, Robert Solow famously remarked that "you see the computer revolution everywhere except in the productivity data" (Solow, 1987). Some ten years later, Alan Greenspan observed that the negative trends in measured productivity observed in many services industries seemed inconsistent with the fact that they ranked among the top computer-using

Note: Earlier versions of this paper were presented at the CRIW/NBER Summer Institute workshop (July 2004), the OECD (March 2005), the BEA (November 2005), and the Joint Meeting of the NBER Labor Studies and Productivity Programs (March 2006). We thank Dale Jorgenson, Darrel Cohen, Larry Slifman, Tom Tallarini, and participants at all workshops for helpful comments. The views expressed in this paper are those of the authors and should not be attributed to the Board of Governors of the Federal Reserve System or other members of its staff.

*Correspondence to: Carol A. Corrado, Economics Programs, The Conference Board, 845 Third Avenue, New York, NY 10022-6600, USA (carol.corrado@conference-board.org).

(C) 2009 The Authors

Journal compilation (C) 2009 International Association for Research in Income and Wealth Published by Blackwell Publishing, 9600 Garsington Road, Oxford OX4 2DQ, UK and 350 Main St, Malden, MA, 02148, USA. 
industries. ${ }^{1}$ Greenspan also questioned the accuracy of the consumer price index, in part because of its failure to adequately account for the new or superior goods made possible by the IT revolution. ${ }^{2}$

The IT revolution began to appear in the productivity data in the mid-1990s. This pickup has been linked to investment in IT capital in a series of papers (Jorgenson and Stiroh, 2000; Oliner and Sichel, 2000, 2002; Jorgenson et al., 2002; Stiroh, 2002), all of which estimate the contribution of IT capital to output growth within the Solow-Jorgenson-Griliches sources-of-growth (SOG) framework. However, the productivity pickup did not remove all suspicion about the ability of official data to accurately capture the factors that affect U.S. economic growth. Both firm-level and national income accounting practice have historically treated expenditure on intangible inputs such as software and R\&D as an intermediate expense and not as an investment that is part of GDP. The exclusion of intangibles obscures the role of many factors at the center of the innovation process that have, according to available evidence, played an important role in economic growth.

This situation has begun to change with the capitalization of software in the U.S. National Income and Product Accounts (NIPAs), which alone had an appreciable effect on the growth of output per worker in the non-farm business sector. ${ }^{3}$ Moreover, the growing literature on intangibles suggests that this is just the tip of the iceberg. ${ }^{4}$ Our own earlier estimates suggest that, in 1999, software spending was less than 15 percent of a more complete list of intangible business investments that includes spending on innovative property (e.g. R\&D) and economic competencies as well as software and other computerized information (Corrado, Hulten, and Sichel, 2005; hereafter CHS). We found that total business investment in intangibles was approximately one trillion dollars in 1999, an amount that is roughly the same as investment in tangible capital at that time. The magnitude of these estimates suggests that uncounted intangibles have an appreciable effect on the level of GDP, as well as on the rate of investment and level of labor productivity. This

${ }^{1}$ Chairman Greenspan's concerns about the measured productivity trends in services industries were first expressed in remarks at an FOMC meeting in late 1996 in regard to a staff analysis of disaggregated productivity trends (Corrado and Slifman, 1999). Gullickson and Harper (1999) also investigated this issue. The observation that many of the services industries that had negative productivity trends were among the top computer-using industries owes, at least in part, to Stiroh (1998) and Triplett (1999).

${ }^{2}$ Similar views were expressed by Nordhaus (1997), who concluded from his analysis of the history of lighting that official price and output data "miss the most important technological revolutions in history." Also, Hausman (1999) noted that cell phones were absent from the CPI market basket for many years after they appeared in the marketplace.

${ }^{3}$ In addition to the capitalization of software expenditures by the Bureau of Economic Analysis (BEA), the capitalization of scientific R\&D is under serious consideration for both the U.S. NIPA and the United Nations System of National Accounts. See Grimm, Moulton, and Wasshausen (2005) for a description of BEA's procedures for estimating software.

${ }^{4}$ See the work sponsored by the OECD (OECD Secretariat, 1998; Khan, 2001) and Nakamura (1999, 2001, 2003), Brynjolfsson and Yang (1999), Brynjolfsson et al. (2002), Hall (2000, 2001a, 2001b), McGrattan and Prescott (2000, 2006), Lev (2001), and Basu et al. (2004). This literature approaches intangibles from various perspectives, and it builds upon previous work that has linked aggregate productivity to stock market performance (e.g. Baily, 1981; Hall and Hall, 1993) and constructed firm-level intangible stocks using financial data (e.g. Griliches, 1981; Cockburn and Griliches, 1988; Hall, 1993). 
paper builds on our previous work by examining whether the relative magnitude of the discrepancy in the level of investment carries over to the rates of growth of capital stock and real output. Our ultimate objective is to examine how the capitalization of intangible expenditures affects the SOG analyses that have played such a prominent role in recent analyses of the productivity pickup.

We use our new SOG estimates to address the following issues: how much growth in output went uncounted because of the omission of intangibles; what is the contribution of intangible capital to output growth; how does the inclusion of intangibles affect the allocation of output growth between capital formation and multifactor productivity growth; and does the post-1995 productivity pickup look different when intangibles are taken into account? To our knowledge, this is the first paper to examine these issues in the SOG framework with a more-or-less complete list of intangible assets.

We find that the inclusion of intangibles makes a significant difference in the measured pattern of economic growth: the growth rates of output and of output per worker are found to increase at a noticeably more rapid rate when intangibles are included than under the baseline case in which intangible capital is completely ignored, and capital deepening (when expanded to include both tangibles and intangibles) becomes the unambiguously dominant source of growth in labor productivity. We also find that the inclusion of intangibles has an important effect on the labor share of income. The \$1 trillion increase in GDP (in 1999) arising from addition of intangible investment to GDP results in an equal increase in Gross Domestic Income (GDI), all of which accrues to the owners of capital. This leads to a significant increase in the share of GDI accruing to capital and a lower share for labor income.

The paper is organized as follows. We first examine the theoretical basis for the claim that intangibles should be treated as capital rather than as intermediate inputs. We then describe how intangible capital, which is often viewed as qualitatively different from tangible capital, can be incorporated in the neoclassical framework on which the sources-of-growth model is based. Our procedures for estimating the flow of intangible investment and the corresponding stock of intangible capital are then discussed, after which our growth accounting results are presented and discussed.

\section{Are Intangibles Really Capital?}

\subsection{The Treatment of Intangible Expenditures}

The first question to be settled is theoretical: Should intangible expenditures be classified as capital or as an intermediate good? The logic underlying the two alternatives becomes more apparent when the production functions and accounting identities associated with the two approaches are made explicit. This can be accomplished by considering a world of three goods, consumption $\mathrm{C}$, tangible investment goods I, and an intangible N. When intangibles are regarded as being an intermediate good, labor $\mathrm{L}$ and tangible capital $\mathrm{K}$ are allocated to the production of all three goods, and $\mathrm{N}$ is an input to $\mathrm{C}$ and $\mathrm{I}$. The production function and flow account for each of the three sectors is then: 


$$
\begin{aligned}
N(t)= & F^{N}\left(L_{N}(t), K_{N}(t), t\right) ; P^{N}(t) N(t)=P^{L}(t) L_{N}(t)+P^{K}(t) K_{N}(t) ; \\
& I(t)=F^{I}\left(L_{I}(t), K_{I}(t), N_{I}(t), t\right) ; \\
& P^{I}(t) I(t)=P^{L}(t) L_{I}(t)+P^{K}(t) K_{I}(t)+P^{N}(t) N_{I}(t) ; \\
& C(t)=F^{C}\left(L_{C}(t), K_{C}(t), N_{C}(t), t\right) \\
& P^{C}(t) C(t)=P^{L}(t) L_{C}(t)+P^{K}(t) K_{C}(t)+P^{N}(t) N_{C}(t) ;
\end{aligned}
$$

with the adding up conditions $L=L_{N}+L_{I}+L_{C}, K=K_{N}+K_{I}+K_{C}$, and $N=N_{I}+$ $N_{C}$, as well as the accumulation equation $K(t)=I(t)+\left(1-\delta_{K}\right) K(t-1){ }^{5}$ The production functions in each equation are linked to the accounting identities by the assumption that each input is paid the value of its marginal product. In this formulation, $N(t)$ is both an output and an intermediate input to the production of the other products, and therefore nets out in the aggregate. Thus, $N(t)$ does not appear in the GDP identity, which has the form:

$$
P^{Q^{\prime}}(t) Q^{\prime}(t)=P^{C}(t) C(t)+P^{I}(t) I(t)=P^{L}(t) L(t)+P^{K}(t) K(t) .
$$

This is the approach taken by financial accounts for individual firms, the United Nation's System of National Accounts (United Nations, 1993), and, until the recent move to capitalize software, the U.S. NIPAs. In equation (1d), the primes on the left-hand side of the equation are used to distinguish the case in which intangibles are excluded from the case described below in which intangibles are counted as investment.

A different model of production accounting applies when the intangible is classified as capital. The output of the intangible, $N(t)$, now appears in the production functions of the consumption and tangible investment sectors as a cumulative stock, not as a contemporaneous input as above. An accumulation equation for intangible capital, $R(t)=N(t)+\left(1-\delta_{R}\right) R(t-1)$, parallels the corresponding equation for tangibles. The sectoral equations become:

$$
\begin{aligned}
& N(t)=F^{N}\left(L_{N}(t), K_{N}(t), R_{N}(t), t\right) ; \\
& P^{N}(t) N(t)=P^{L}(t) L_{N}(t)+P^{K}(t) K_{N}(t)+P^{R}(t) R_{N}(t) ;
\end{aligned}
$$

$$
\begin{aligned}
& I(t)=F^{I}\left(L_{I}(t), K_{I}(t), R_{I}(t), t\right) \\
& P^{I}(t) I(t)=P^{L}(t) L_{I}(t)+P^{K}(t) K_{I}(t)+P^{R}(t) R_{I}(t)
\end{aligned}
$$

$$
\begin{aligned}
& C(t)=F^{C}\left(L_{C}(t), K_{C}(t), R_{C}(t), t\right) ; \\
& P^{C}(t) C(t)=P^{L}(t) L_{C}(t)+P^{K}(t) K_{C}(t)+P^{R}(t) R_{C}(t) .
\end{aligned}
$$

${ }^{5}$ We adopt the convention that intermediates used by the industry that produced them are netted out of final output. We have therefore omitted $N_{N}$ from the production function and accounts of the intermediate good industry. We also ignore the complication of chain weighting to keep the exposition simple. 
The balance equations set out above are modified to replace the equation $N=N_{N}+N_{I}+N_{C}$ with $R=R_{I}+R_{C}+R_{N} \cdot{ }^{6}$ Again, the production functions in each equation are linked to the accounting identities by the assumption of marginal productivity pricing. The GDP identity, in this case, must be expanded to included the flow of new intangibles on the product side and the flow of services from the intangible stock on the income side:

$$
\begin{aligned}
P^{Q}(t) Q(t) & =P^{C}(t) C(t)+P^{I}(t) I(t)+P^{N}(t) N(t) \\
& =P^{L}(t) L(t)+P^{K}(t) K(t)+P^{R}(t) R(t) .
\end{aligned}
$$

The price $P^{R}(t)$ is the user cost associated with the services of the intangible stock which is a source of income that is absent from the conventional intermediate goods case (1d). The concept of GDP in this expanded identity is more comprehensive and larger in magnitude than in the conventional case.

\subsection{Growth Accounting with Intangible Capital}

The conventional SOG framework allocates the growth rate of output to the share-weighted growth rates of the inputs plus a residual. Following Solow (1957), the SOG equation is derived from the conventional framework of equations (1a)(1d) by logarithmic differentiation of (1d):

$$
\begin{aligned}
g_{Q^{\prime}}(t) & =s_{C}^{\prime}(t) g_{C}(t)+s_{I}^{\prime}(t) g_{I}(t) \\
& =s_{L}^{\prime}(t) g_{L}(t)+s_{K}^{\prime}(t) g_{K}(t)+g_{A^{\prime}}(t) .
\end{aligned}
$$

The notation $g_{X}(t)$ is used to denote the rate of growth of the respective variables; for example, $g_{Q^{\prime}}(t)$ thus denotes the growth rate of aggregate output (the Divisia index of the growth rates of consumption, $g_{C}(t)$, and investment, $\left.g_{I}(t)\right)$, and $g_{A^{\prime}}(t)$ denotes the growth rate of multifactor productivity (MFP) defined in the usual way. The output shares $s_{C}^{\prime}(t)=\left[P^{C}(t) C(t)\right] /\left[P^{C}(t) C(t)+P^{I}(t) I(t)\right]$, etc, and input shares $s_{L}^{\prime}(t)=\left[P^{L}(t) L(t)\right] /\left[P^{L}(t) L(t)+P^{K}(t) K(t)\right]$, etc, are assumed to be equal to the corresponding output elasticities. Intangible input and output play no role in the formulation of this SOG equation.

When intangible capital is treated symmetrically with tangibles, the structure (2a)-(2d) governs the equations of growth, and the SOG model becomes:

$$
\begin{aligned}
g_{Q}(t) & =s_{C}(t) g_{C}(t)+s_{I}(t) g_{I}(t)+s_{N}(t) g_{N}(t) \\
& =s_{L}(t) g_{L}(t)+s_{K}(t) g_{K}(t)+s_{R}(t) g_{R}(t)+g_{A}(t),
\end{aligned}
$$

${ }^{6}$ In this second formulation we expand the technology of the intangible producing sector to use the output that it produced in previous years (that is, to use its own stock of accumulated intangibles). In other words, the knowledge investments of past years are allowed to be productive in producing current and future knowledge. This allows investment to be aimed not just at direct product or process innovation, but also at furthering the capability of the innovation process itself. Indeed, this is a key aspect of the $R \& D$ process, because research is often done to further the research capability of $R \& D$ researchers. Moreover, some firms continue to do research even when a competitor has beat them to the punch, in order to keep up with best practice and perhaps get out in front in the next round. This line of reasoning does not fit well with the preceding formulation (1a)-(1d) in which the accumulated stock of past knowledge is treated as an intermediate input and omitted from the technology for producing knowledge. 
where the output shares are now $s_{C}(t)=\left[P^{C}(t) C(t)\right] /\left[P^{C}(t) C(t)+P^{I}(t) I(t)+\right.$ $\left.P^{N}(t) N(t)\right]$, etc., and the true input shares are $s_{L}(t)=\left[P^{L}(t) L(t)\right] /\left[P^{L}(t) L(t)+\right.$ $\left.P^{K}(t) K(t)+P^{R}(t) R(t)\right]$, etc.

A comparison of (1e) and (2e) reveals that the alternative view of intangibles involves more than the growth terms $g_{N}(t)$ and $g_{R}(t)$, and the associated shares, but also requires a restatement of all shares. The shares are linked by the factor of proportionality:

$$
\lambda=\left(p^{C} C+p^{I} I\right) /\left(p^{C} C+p^{I} I+p^{N} N\right) .
$$

The basic result is that labor's share when intangibles are capitalized is smaller by this factor: $s_{L}=\lambda s_{L}^{\prime}$, and the income share of capital is thus larger. A similar analysis applies to the rates of saving and consumption. Consumption shares with and without intangibles are related by the same proportionality factor as above, $s_{C}=\lambda s_{C}^{\prime}$. The consumption share is smaller and the rate of saving/investment is correspondingly higher. This result is relevant in view of the perception of a low rate of saving in the U.S. economy, particularly because existing measures exclude much of the investment in knowledge capital that is a defining feature of the modern U.S. economy. Finally, the residual estimates of multifactor productivity from (1e) and (2e), $g_{A^{\prime}}(t)$ and $g_{A}(t)$, respectively, differ by the factor $\lambda$ when the economic system is in Golden Rule steady state growth, a result derived from Jorgenson (1966), but the bias due to ignoring intangible capital, $g_{A}(t)-g_{A^{\prime}}(t)$, has a more complicated form in other cases.

\subsection{The Criteria for Capitalizing Intangibles}

The two approaches set out above give different structural representations of the same economy, and both cannot be simultaneously correct. Fortunately, standard capital theory provides criteria for choosing one over the other. As discussed in CHS, capital theory implicitly defines capital in the context of an optimal consumption plan based on the maximization of an intertemporal utility function subject to the usual constraints (Weitzman, 1976). The solution to this optimization problem determines the optimal path of consumption over time and thus consumer saving behavior, which in turn determines the paths of investment and capital. As discussed in Hulten (1979), the solution to this optimization problem has an important implication for the treatment of intangible capital: any use of resources that reduces current consumption in order to increase it in the future qualifies as an investment. This result argues for symmetric treatment of all types of capital and that business expenditures aimed at enhancing the value of a firm and improving its products, including human capital development as well as R\&D, be accorded the same treatment as tangible capital in national accounting systems.

The symmetry between tangible and intangible capital is less apparent from the production side of the economy, which is perhaps one reason that intangibles have traditionally not been counted as capital. Indeed, some have arguedparticularly in the accounting world - that intangible assets often are produced within the firm that uses them, and the marketplace does not generate observable and verifiable data with which to estimate the value of current production, 
designated as the flow $P^{N}(t) N(t)$ in the notation of this paper. A related problem arises because it is also difficult to separate $P^{N}(t) N(t)$ into separate price and quantity components; indeed, sometimes it is even difficult to define the units in which $P^{N}(t)$ and $N(t)$ ought to be measured (for example, in what units should knowledge be denominated?).

The lack of verifiability per se does not automatically make intangibles an intermediate input. Some tangible assets are also produced internally (some construction projects, for example) and therefore do not pass through external markets that generate verifiable transactions data. On the other hand, many intangible assets are acquired through external markets (technology licenses, patents and copyrights, and the economic competencies acquired through purchases of management and consulting services). In any case, the real issue of whether intangibles should be classified as intermediates or as capital depends on the economic character of the good, as per the preceding discussion, and not on the ease with which $P^{N}(t) N(t)$ can be measured.

The non-rivalness of many types of intangible capital, such as R\&D knowledge, implies that it can be employed by many users simultaneously without diminishing the quantity available to any single user. In this situation, the balance equations would be $N=N_{N}=N_{I}=N_{C}$ and $R=R_{I}=R_{C}=R_{N}$. Moreover, each additional unit of output produced would not need an additional "unit" of knowledge, suggesting that the marginal product of $R$ is zero. While the marginal product of $R$ used in the direct production of output may indeed be zero, this is the wrong margin to examine when a firm pays to increase its $R$ and the increase improves the efficiency of its production or quality (and hence quantity) of its output. In addition, many types of intangible capital — such as brand equity and organizational and human competencies - are not purely non-rival, but instead are firm-specific and valuable, at least in part, because the firm is able to exclude competitors from gaining access to key information and technology.

The non-appropriability of some intellectual property is a related aspect of intangibles. The full benefits of R\&D and worker training may not be captured by the firm making the investment, and the measured prices $P^{N}(t)$ and $P^{R}(t)$ may reflect only private benefits and costs. ${ }^{7}$ However, as before, the capitalization issue pivots on whether the provision of $R$ increases future output and consumption, not whether $R$ is partly non-appropriable or non-rival, and these two features do not invalidate the need to capitalize many intangible expenditures. That is determined by whether or not the expenditure is intended to yield output in some future time period. This is the conceptual analogue on the production side to the symmetry criterion of whether the expenditure was made in order to increase future consumption. Many intangibles satisfy these criteria and must therefore be treated as capital.

Symmetry in production does impose one important restriction on intangible assets. To proceed as we have in the formulation of the equations (2a)-(2d), we assume that the same neoclassical investment rules that apply to tangible capital

${ }^{7}$ Any externalities due to unappropriated benefits from R\&D or other investments appear as a shift in the production function and are picked up in measured MFP (Hulten, 2001). This is essentially the mechanism of endogenous growth theory when externalities arise from R\&D (Romer, 1986) and education (Lucas, 1988). 
also apply to intangibles: investment in tangibles is assumed to proceed up to the point that the present value of the stream of future user costs, $P^{K}(t+\tau)$ just equals the cost of acquiring a marginal unit of the investment good, $P^{I}(t)$. Applied to intangibles, this assumption implies that investment is made using marginalist principles. An alternative Schumpetarian view of the firm might reject this assumption, but we adopt the marginalist approach because our objective is to integrate intangible capital into the neoclassical sources-of-growth framework of equation (2e), which is based on marginalist principles.

\subsection{Prices and Deflators}

The SOG equations of the preceding section are computationally derived from the accounting structure in equations (2a)-(2d) using price deflators to convert nominal values into their real counterparts. As discussed above, a difficult aspect of this computation is measuring the price deflator $P^{N}(t)$ needed to convert estimates of expenditure $P^{N}(t) N(t)$ into real estimates. This has proved to be one of the most difficult empirical issues in the study of R\&D investment, in large part because of the verifiability and visibility issues described above. The strategy in the R\&D literature has been to use input costs to proxy for $P^{N}(t)$; the most common approach has been to average a wage deflator and a price deflator for a broad measure of output on the grounds that R\&D expenditures are roughly 50 percent labor costs and 50 percent supplies (Jaffe, 1972; Griliches, 1984).

In contrast to this approach, we opt for a pure output deflator as a proxy for the price of intangibles. Although we consider this proxy only a placeholder until further research develops deflators for specific intangibles, we believe that a price measure is preferred to a wage measure for the following reason. Under constant returns to scale in the technology in (2a), the growth rate of the price of the intangible capital good is:

$$
g_{P N}(t)=s_{L N}(t) g_{P L}(t)+s_{K N}(t) g_{P K}(t)+s_{R N}(t) g_{P R}(t)-g_{A N}(t),
$$

where $s_{L N}(t)=\left[P^{L}(t) L_{N}(t)\right] /\left[P^{L}(t) L_{N}(t)+P^{K}(t) K_{N}(t)+P^{R}(t) R_{N}(t)\right]$ is labor's income share in the production of intangible investment, $g_{P N}$ is the growth rate of the price of the intangible good, and the other share and growth rate terms are defined analogously. Using the wage $P^{L}(t)$ as a proxy for $P^{N}(t)$ is equivalent to assuming that the growth rate of the output price is $g_{P N}(t)$ is equal to the growth rate of wages, $g_{P L}(t)$. As can be seen in equation (4), this will occur only if labor is the sole input to the production of the intangible and if the rate of multifactor productivity growth in the production of intangibles, $g_{A N}(t)$, and the shares of tangible and intangible capital, $s_{K N}(t)$ and $s_{R N}(t)$, are all zero. These assumptions are extremely implausible, because, for example, R\&D programs require plant and equipment, and knowledge builds on knowledge. Because using a wage deflator tends to give biased results, we adopt the non-farm business output price deflator as a proxy for $P^{N}(t)$. This proxy can be rationalized by the fact that much R\&D and coinvestments in marketing and human competencies are tied to specific product lines. Integrating the cost of productivity-enhancing investments back into the "using" 
industries is accomplished generally by adopting the non-farm business output price as the deflator for intangibles. ${ }^{8}$

The search for an appropriate deflator for the user cost of intangibles, $P^{R}(t)$, also poses challenges. The corresponding user cost of tangible capital, $P^{K}(t)$, is not usually observed but can be imputed following Jorgenson (1963) and Hall and Jorgenson (1967). When intangibles are ignored, the conventionally measured rental flow, $P^{K}(t) K(t)$, is estimated by the residual income not attributable to labor, $P^{C}(t) C(t)+P^{I}(t) I(t)-P^{L}(t) L(t)$. This leads to an error because, when income accrues to intangible capital, the conventionally measured residual term for capital income actually equals

$$
P^{C}(t) C(t)+P^{I}(t) I(t)-P^{L}(t) L(t)=P^{K}(t) K(t)+P^{R}(t) R(t)-P^{N}(t) N(t) .
$$

The conventional practice of ignoring intangible capital thus leads, in general, to a biased estimate of the income accruing to tangible capital. There is, moreover, another subtle issue that arises because the total capital income on the right-hand side of (5) is measured by the sum of all property-type income (interest, dividends, retained earnings, taxes, and depreciation). This list accounts for all the non-labor payments accruing to both tangible and intangible capital, i.e. to $P^{K}(t) K(t)+$ $P^{R}(t) R(t)$, leaving no apparent role for the intangible investment, $P^{N}(t) N(t)$. As the right-hand side of equation (5) illustrates, the answer to this apparent contradiction is that the income accruing to intangible investments is reflected on the input side as uncounted profits. Specifically, when intangibles are treated as an intermediate input, the spending on intangibles is subtracted from revenue as an expense, reducing measured profits. On the other hand, when intangibles are treated as an investment, they are not subtracted from revenue in the period of purchase, and profits are higher. Thus, the symmetric treatment of tangible and intangible capital is not just about $P^{N}(t) N(t)$ as uncounted output, but also about $P^{N}(t) N(t)$ as uncounted income accruing to capital.

\section{Estimates of Intangible InVEstment And CAPItal}

\subsection{Measuring Investment in Intangibles}

In our earlier work, we developed estimates of a broad range of business investments in intangibles in the 1990s. We first introduced basic categories of intangibles and suggested specific types of intangible spending within each category. We then estimated expenditures on each type of intangible and, based on available economic research and evidence, determined how much of each expenditure type might be considered business investment according to the criterion of whether the expenditure could be deemed to yield future consumption.

The rationale for our choice of categories is discussed in some detail in our previous paper. We only note here that the choice was driven, in large part, by our desire to go beyond existing categories to develop a more comprehensive list. Our first broad category, business investment in computerized information, is largely

${ }^{8}$ Martin Baily offered this rationale for the deflation of the output of management consultancies (see Triplett and Bosworth, 2004, p. 260). 
composed of the NIPA series for business investment in computer software. ${ }^{9}$ Our second category, innovative property, includes the National Science Foundation (NSF) Industrial R\&D series. However, the NSF's survey is designed to capture innovative activity built on a scientific base of knowledge and therefore does not fully capture resources devoted by businesses to innovation and new product/ process R\&D more broadly. This "other" R\&D-we called it non-scientific R\&D - includes the revenues of the non-scientific commercial R\&D industry, as measured in the Census Bureau's Services Annual Survey (SAS), the costs of developing new motion picture films and other forms of entertainment, investments in new designs, and a crude estimate of the spending for new product development by financial services and insurance firms. ${ }^{10} \mathrm{We}$ found that, by the late 1990s, investment in non-scientific R\&D was as large as investment in scientific R\&D.

Our third general category includes investment in what we have called "economic competencies." This includes spending on strategic planning, spending on redesigning or reconfiguring existing products in existing markets, investments to retain or gain market share, and investments in brand names. Expenditures for advertising are a large part of the investments in brand equity, but as stressed in our earlier work, not all spending on intangibles should be counted as capital spending. Based on results from the empirical literature on advertising, we estimated that only about 60 percent of total advertising expenditures were for ads that had long-lasting effects (that is, effects that last more than one year compared with ads for, say, "this week's sale").

Investment in firm-specific human and structural resources is the second type of economic competency included in our estimates. It includes the costs of employer-provided worker training and an estimate of management time devoted to enhancing the productivity of the firm. Our estimates of the former are based on Bureau of Labor Statistics (BLS) surveys; the latter are based on SAS revenues for the management consultant industry and trends in the cost and number of persons employed in executive occupations. Without doubt, these spending flows are imprecisely estimated, but business investments in firm-specific human and structural resources through strategic planning, adaptation, reorganization, and employee-skill building are important drivers of innovation and profitability in industry and require treatment as investment to be consistent with capital theory. ${ }^{11}$ Moreover, this last category is, by our reckoning, the largest type of business intangible investment. And, total investment in economic competencies is nearly as large as the investment in the other two major categories combined.

${ }^{9}$ The NIPA software series is conceptually consistent with our intertemporal criterion for defining capital because the software measure includes both purchased and own-account components. National accountants estimated the own-account component indirectly to overcome the verifiability issue discussed earlier (Parker and Grimm, 1999).

${ }^{10}$ Many new products in the financial services industry involve computerized information; to avoid double-counting (particularly with the own-account portion of computer software), we deliberately were very conservative in our estimates for this component.

${ }^{11}$ Moreover, the microdata evidence of Abowd et al. (2005) suggests that firm-level differences in organizational practices (proxied by firm-level distributions of human capital) are strongly related to outcomes such as revenue per worker and market valuation. A similar conclusion is reached by Bloom and Van Reenen (2007), who find that a firm's productivity, profitability, and market value (relative to the book value of its tangible capital) are all strongly related to an index of management effectiveness. 
Two other facts emerged from our earlier work. First, total investment in intangibles grew more rapidly than investment in tangibles over the decade of the 1990s, although the levels of the two were nearly equal in magnitude for the decade as a whole. Second, investment in the categories of intangibles already included in the NIPAs was only a fraction of our estimated total, even if all scientific R\&D were included. Together, these findings suggest that a longer time series on the growth of intangible business investment would indicate a strong dynamic role for intangibles in explaining economic growth and might significantly affect our understanding of the sources of growth of the U.S. non-farm business sector.

Table 1 reports our new estimates of business investment in the intangibles by decade, starting in 1950. In general, the estimates were derived using the same methods and sources as used in our earlier paper. Most of the needed source data begin at least by the late 1940s, and the series for spending on scientific

TABLE 1

Business INVESTMENT IN INTANGIBLES (BILLIONS OF DOLLARS, ANNUAL AVERAGE FOR PERIOD SHOWN)

\begin{tabular}{|c|c|c|c|c|c|c|}
\hline & $\begin{array}{l}1950-59 \\
(1)\end{array}$ & $\begin{array}{l}1960-69 \\
(2)\end{array}$ & $\begin{array}{l}1970-79 \\
(3)\end{array}$ & $\begin{array}{l}1980-89 \\
(4)\end{array}$ & $\begin{array}{l}1990-99 \\
(5)\end{array}$ & $\begin{array}{c}2000-03 \\
(6)\end{array}$ \\
\hline 1. Total CHS intangibles & 19.4 & 41.9 & 103.4 & 349.3 & 749.8 & $1,226.2$ \\
\hline $\begin{array}{l}\text { 2. Computerized information } \\
\text { (mainly computer software) }\end{array}$ & - & 0.8 & 4.5 & 23.2 & 85.3 & 172.5 \\
\hline $\begin{array}{l}\text { 3. Innovative property } \\
\text { (a) Scientific R\&D } \\
\text { (b) Non-scientific R\&D }\end{array}$ & $\begin{array}{l}7.7 \\
0.5\end{array}$ & $\begin{array}{r}16.9 \\
1.7\end{array}$ & $\begin{array}{l}34.0 \\
10.9\end{array}$ & $\begin{array}{r}104.6 \\
58.4\end{array}$ & $\begin{array}{l}157.7 \\
145.2\end{array}$ & $\begin{array}{l}230.5 \\
237.2\end{array}$ \\
\hline $\begin{array}{l}\text { 4. Economic competencies } \\
\text { (a) Brand equity } \\
\text { (b) Firm-specific resources }\end{array}$ & $\begin{array}{l}5.3 \\
5.9\end{array}$ & $\begin{array}{r}9.5 \\
13.0\end{array}$ & $\begin{array}{l}18.2 \\
35.7\end{array}$ & $\begin{array}{r}54.4 \\
108.7\end{array}$ & $\begin{array}{l}105.7 \\
255.9\end{array}$ & $\begin{array}{l}160.8 \\
425.1\end{array}$ \\
\hline Related series $^{1}$ & & & & & & \\
\hline 5. Computer software, NIPAs & - & 0.7 & 4.5 & 22.7 & 83.6 & 169.6 \\
\hline 6. Industrial R\&D, NSF ${ }^{2}$ & 5.2 & 14.1 & 25.3 & 75.8 & 136.9 & 196.0 \\
\hline 7. Advertising, Coen report & 8.6 & 15.0 & 30.6 & 89.6 & 165.0 & 240.3 \\
\hline $\begin{array}{l}\text { 8. Business fixed investment, } \\
\text { NIPAs }\end{array}$ & 38.2 & 71.5 & 188.4 & 485.7 & 807.1 & $1,141.9$ \\
\hline 8a. Tangibles & 35.6 & 67.3 & 171.4 & 421.1 & 676.5 & 893.4 \\
\hline 8b. Intangibles ${ }^{3}$ & 2.5 & 4.2 & 17.0 & 64.6 & 130.7 & 248.5 \\
\hline Memo: & & & & & & \\
\hline $\begin{array}{l}\text { 9. CHS intangibles, ratio to } \\
\text { NIPA tangibles }\end{array}$ & 0.54 & 0.62 & 0.60 & 0.82 & 1.10 & 1.36 \\
\hline 10. New CHS intangibles ${ }^{4}$ & 16.9 & 37.7 & 86.3 & 284.7 & 619.2 & 977.7 \\
\hline $\begin{array}{l}\text { 11. Non-farm business output, } \\
\text { ratio of existing to adjusted } \\
\text { for new CHS intangibles }(\lambda)\end{array}$ & 0.95 & 0.94 & 0.94 & 0.92 & 0.90 & 0.89 \\
\hline
\end{tabular}

Notes: All figures for investments in intangibles are derived using the sources and methods described in CHS, based on a one-year service life cutoff.

${ }^{1}$ Sources indicated are as follows: NIPAs, the U.S. National Income and Product Accounts; NSF, the National Science Foundation; and Coen report, advertising data developed by Bob Coen for Universal-McCann.

${ }^{2}$ Prior to 1953 , the industrial R\&D estimates are from N. Terleckyj (1963).

${ }^{3}$ Includes computer software, mineral exploration, and architectural and design services embedded in structures and equipment purchases.

${ }^{4}$ Intangibles not recognized as capital in the NIPAs. 
R\&D and on brand equity begin much earlier. However, for a few components we could not use the same sources for earlier periods, and the components were extrapolated backward in time using related series. This occurred most prominently for the series based on SAS data, which are not available prior to the mid-1980s. All SAS series were extrapolated back to the late 1940s using a related aggregate in the BEA's gross product by industry system. ${ }^{12}$

For employer-provided training we made some changes to the estimates for recent years and made some special adjustments to estimates for earlier years. In our earlier work, we used trends in wage costs and the industrial structure of the workforce to extrapolate the results of surveys conducted by the BLS in the mid-1990s. For this paper, we improved our extrapolations for more recent years by linking them to estimates from surveys that have been conducted by the American Society for Training and Development (ASTD) since 1997. ${ }^{13}$ These new results suggest a slight pullback in firms' per-employee expenditure on training in 2002, perhaps reflecting the cyclical episode in 2001. We know of no similar survey-based data for business outlays on employer-provided training in earlier periods.

The studies that established the link between training and productivity at the firm level (Bartel, 1991, 1994) used data for earlier years (the mid-1980s), but the training measures were qualitative indicators, not actual figures on the amount firms invested in their employees (see also Black and Lynch (1996), whose data were for the early 1990s). The BLS surveys and the more recent ASTD data suggest that per-employee rates of spending on (formal) training increases with the size of the firm. ${ }^{14}$ The BLS surveys also show that employees in professional and managerial occupations receive the most training (in terms of hours). ${ }^{15}$ With the growth of the modern corporation and a rough doubling of the ratio of employees in professional and managerial occupations in the total workforce since the late 1960s, the incidence of employer-provided training likely has also increased by a notable, albeit unknown, amount. ${ }^{16}$ Because an extension of the methods used in our earlier work would not build in an increase in incidence (except indirectly through its impact on the distribution of wage costs by industry), we boosted the trend in training implied by an extension of our earlier work by a small amount (less than 2 percent per year) between 1948 and 1988.

\footnotetext{
${ }^{12}$ Specifically, the rate of change in value added in miscellaneous professional services was used to extend the series for R\&D in the social sciences and humanities, market research services, and management consulting services from 1985 back to 1947.

${ }^{13}$ See www.astd.org or Bassi et al. (2001) for further information.

${ }^{14}$ See table 1 in the employer survey at www.bls.gov/ept. Only 69 percent of small establishments (fewer than 50 employees) provided formal training in 1995 compared with nearly all medium-sized (50-249 employees) and large (250 or more employees) establishments.

${ }^{15}$ Employees in professional and paraprofessional occupations received essentially twice the number of hours of formal and informal training as those in other occupational groups, with training most prevalent for computer, professional and technical, and management skills. See tables 1 and 6 in the employee survey at www.bls.gov/ept.

${ }^{16}$ The reported increase in the ratio of professional and managerial occupations in the workforce is based on data from BLS's Current Population Survey (CPS). Nakamura (2001) presents and discusses the increase in this ratio from 1982 to 2000 . We developed similar estimates using more limited CPS occupational categories that extend back to 1967.
} 


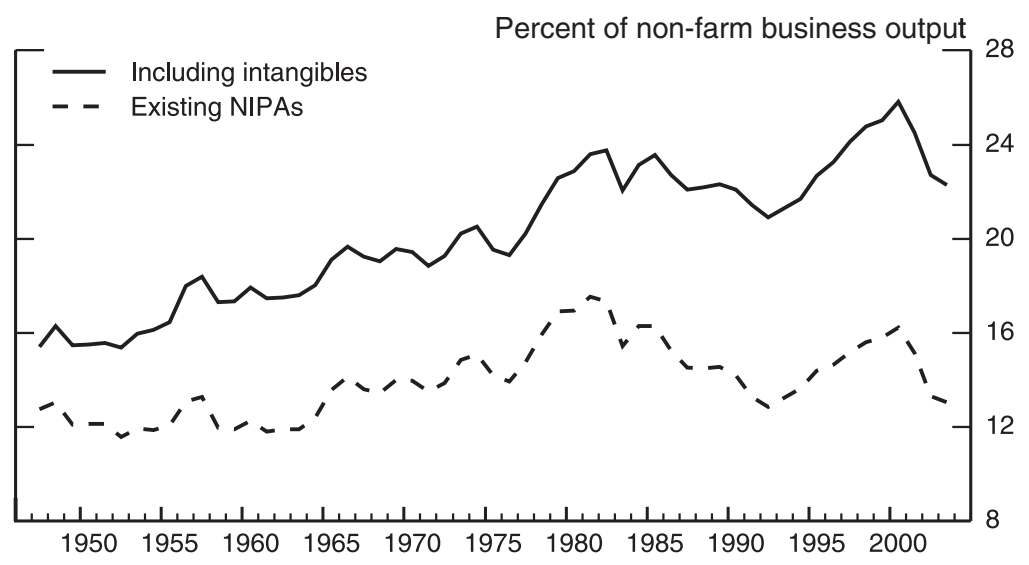

Figure 1. Investment Shares

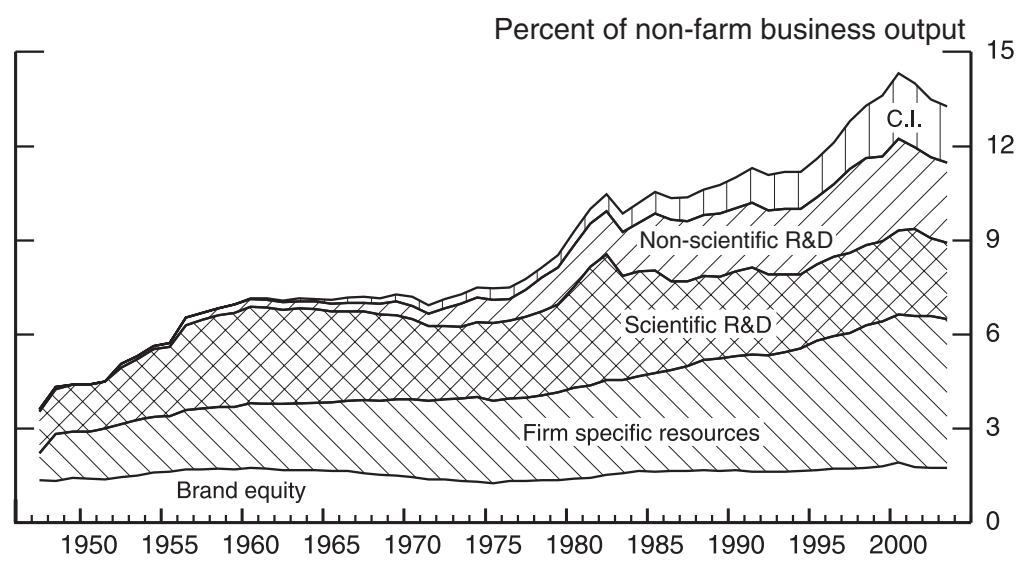

Figure 2. Intangible Shares

Note: C.I. $=$ Computerized information .

All told, business investment in intangibles is a vital aspect of business activity, and the investments shown in table 1 represent a large and growing portion of the overall economy. The extent to which existing nominal output measures are understated owing to the treatment of most intangibles as intermediates in the national accounts is illustrated by Figures 1 and 2. The former shows our measure of total investment as a share of (adjusted) non-farm business output and indicates that intangibles have accounted for virtually all of the increase over the last five decades. (Note that software is included in "existing" investment, owing to its current treatment the NIPAs.) Figure 2 breaks the growth in intangible investment into its major components and shows that, in recent years, the most dynamic categories of intangibles are firm-specific resources, non-scientific R\&D, and computer software. The major period of relative growth in scientific $R \& D$ was the 
1950s. ${ }^{17}$ Figure 2 also shows the relative importance of investment in economic competencies as a share of the total investment.

The last four rows of Table 1 present data on related series as a basis for further comparisons. The most interesting is perhaps the last row, which presents our estimates of the parameter $\lambda$ from our equation (3). This parameter is the ratio of output with and without unrecognized intangibles. When non-farm business output is adjusted to include our estimates of the unrecognized intangibles, the adjusted output is 12 percent $(1 / \lambda-1$, expressed as a percent) higher than the existing measure in the $2000-03$ period. Fifty years ago, the adjusted measure was only about 5 percent higher.

\subsection{Real Intangible Investment and Capital Stocks}

The ultimate objective is to estimate the SOG equation (2e). In order to do this, estimates of the real investment in intangibles are necessary, as are the corresponding stocks of capital. Real investment for each new category of intangibles was obtained by deflating the nominal investment estimates of the preceding section by the non-farm business output deflator. ${ }^{18}$ As noted in Section 2, we believe this deflator is a plausible placeholder until further research permits better measures. The NIPA price index for software is retained and used for that category of intangibles.

To obtain intangible capital stocks, we start with our estimates of real investment series $N(t)$ and apply the capital accumulation identity of Section II, $R(t)=N(t)+\left(1-\delta_{R}\right) R(t-1){ }^{19}$ Two further elements beyond $N(t)$ are needed to implement the identity: a depreciation rate, $\delta$, and a capital benchmark, $R(0)$, for each intangible asset.

Relatively little is known about depreciation rates for intangibles. Based on the limited information available, we made the following assumptions about depreciation rates:

\section{Category}

Computerized information (other than software)

R\&D, scientific

R\&D, non-scientific

Brand equity

Firm-specific resources

\section{Depreciation Rate (percent)}

20

60

40

\footnotetext{
${ }^{17}$ Scientific R\&D also bulged in the $1979-82$ period, but this bulge is accounted for by a jump in mineral exploration, which we include in scientific R\&D along with the NSF's Industrial R\&D series. Expenditures on oil and gas well drilling and mining, the dominant component of mineral exploration, are already capitalized in the NIPAs.

${ }^{18}$ The non-farm business output deflator begins in 1948. To deflate nominal investment data that begin earlier (scientific R\&D and brand equity, for example), the non-farm business output deflator is linked to the GDP deflator.

${ }^{19}$ Note that we are assuming that $R \& D$ investment becomes productive as soon as it is put in place; that is, we are assuming a gestation lag of zero. In contrast, Fraumeni and Okubo (2005) assumed a one-year gestation lag. We maintained a gestation lag of zero to avoid the complication of different gestation lags for different assets as is done in much of the growth accounting literature. Hopefully, future research will shed further light on this issue.
} 
For computerized information, our estimate is based on the BEA's assumptions for own-account software (depreciation rate of 33 percent, five-year service life). Our estimate of the depreciation rate of $R \& D$ capital (20 percent) is in the middle of the range of the rates reported in the existing literature on R\&D. For R\&D, Bernstein and Mamuneas (2006) find that the depreciation rate in the United States is 18 percent. Nadiri and Prucha (1996) obtain a figure of 12 percent. Pakes and Schankerman (1978), using data for several European countries, obtain an average rate of 25 percent; in a later paper (Pakes and Schankerman, 1986), they estimate a range of $11-26$ percent. ${ }^{20}$ For advertising, the empirical literature finds the effects of ads to be relatively short-lived (as noted earlier) but reports a wide range of findings on the longevity of advertising capital; our own interpretation of this literature is that advertising capital depreciates by 60 percent per year. ${ }^{21}$

For firm-specific resources, we averaged the rates for brand equity and R\&D. As just described, the firm-specific resources category has two components. On the one hand, the discernible and direct link between employer-provided training and firm-level productivity suggests that investments in this component are longlasting. On the other hand, investments through strategic planning and reorganization reflect the need of business to constantly adapt to changing economic conditions. While such investments undoubtedly have a long-lasting "learning-bydoing" dimension (similar to that in R\&D), we believe they also have a short-lived "organizational forgetting" dimension (similar to that in advertising).

For each asset, the initial capital stock was set to zero in the year shown below.

\section{Category}

Computerized information

R\&D, scientific

R\&D, non-scientific

Brand equity

Firm-specific resources

\section{Year Initial Stock Set to Zero}
1958
1928
1945
1928
1946

The assumption that initial capital stocks are zero (rather than an unknown positive value) has little effect on our growth accounting analysis because all of the depreciation rates are relatively high and the true value of the benchmark will have depreciated away by the date that we start our growth accounting analysis (1973).

Table 2 shows our estimate of the nominal intangible capital stock in 2003 (in billions of dollars) and the annual average growth rate of real intangible capital

\footnotetext{
${ }^{20}$ The 33 percent figure is the double-declining balance rate for BEA's assumed service life of five years for own-account software, calculated as 1.65/5. This ratio was originally developed by Hulten and Wykoff (1981).

${ }^{21}$ We concluded that advertising had a service life of less than 3 years based on work by Landes and Rosenfield (1994) who estimated implied annual geometric rates of decay of advertising for 20 two-digit SIC industries covering manufacturing and many services. The Landes-Rosenfield findings also generated our conclusions on the amount of advertising that should be expensed (about 40 percent; see footnote 21 in CHS). The literature is not settled on these issues. Some find that all (Comanor and Wilson, 1974) or a higher fraction (Hall, 1993) of advertising expenditures should be expensed, while others suggest that little or no expensing is appropriate (Lev, 2001). Yet another econometric study found the durability of advertising capital to be as high as 7 years (Ayanian, 1983).
} 
TABLE 2

Value, Growth Rate, and Income Share of Business Intangible Capital

\begin{tabular}{|c|c|c|c|c|c|}
\hline & \multirow{2}{*}{$\begin{array}{c}\begin{array}{c}\text { Value } \\
\text { (billions } \\
\text { of dollars) }\end{array} \\
2003\end{array}$} & \multicolumn{2}{|c|}{$\begin{array}{l}\text { Growth Rate of } \\
\text { Real Capital }^{1} \\
\text { (percent change) }\end{array}$} & \multicolumn{2}{|c|}{$\begin{array}{l}\text { Share of Total } \\
\text { Income (percent) }\end{array}$} \\
\hline & & $1973-95$ & $1995-2003$ & $1973-95$ & $1995-2003$ \\
\hline 1. Total & $3,636.1$ & 6.2 & 6.9 & 9.4 & 13.9 \\
\hline $\begin{array}{l}\text { 2. Computerized information } \\
\text { (includes software) }\end{array}$ & 511.9 & 16.0 & 13.0 & 0.8 & 2.3 \\
\hline \multicolumn{6}{|l|}{ 3. Innovative property } \\
\hline 3a. Scientific & 922.3 & 3.6 & 3.9 & 2.4 & 2.5 \\
\hline 3b. Non-scientific & 864.4 & 12.4 & 7.2 & 1.0 & 2.2 \\
\hline \multicolumn{6}{|l|}{ 4. Economic competencies } \\
\hline 4a. Brand equity & 271.8 & 4.2 & 4.6 & 1.7 & 2.0 \\
\hline 4b. Firm-specific resources & $1,065.6$ & 5.3 & 6.2 & 3.5 & 5.0 \\
\hline \multicolumn{6}{|l|}{ Мето: } \\
\hline 5. New CHS intangibles & $3,132.9$ & 4.7 & 4.6 & 8.6 & 11.7 \\
\hline
\end{tabular}

Note: ${ }^{1}$ The rates of change for the total and major categories are built from the individual real stocks using asset-specific user costs as price weights.

Source: Authors' calculations.

in the 1973-95 and 1995-2003 periods. ${ }^{22}$ In terms of the components of intangible capital, over the period 1973-95, non-scientific R\&D capital is the fastest growing new category of intangibles; over the period 1995-2003, computerized information is the fastest growing category. In both periods, scientific R\&D is the slowest growing category.

\subsection{The User Cost of Intangible Capital}

The SOG model (2e) requires both the growth rate of intangible capital and its income share. In order to estimate the income share, it is first necessary to estimate the user cost $P^{R}(t)$ associated with each type of intangible capital. The standard expression for the user cost of any asset was derived by Jorgenson (1963) and extended by Hall and Jorgenson (1967) to include taxes. The Jorgensonian user cost for intangibles is given by the expression

$$
P_{i}^{R}(t)=\left[r(t)+\delta_{i}-\pi_{i}(t)\right] P_{i}^{N}(t),
$$

where $r(t)$ a measure of the net rate of return common to all capital in year $t, \delta_{i}$ is the depreciation rate for asset $i, \pi_{i}(t)$ is the expected capital gain (loss) on asset $i$, and $P_{i}^{N}(t)$ is the intangible investment price deflator. Except for the real net rate of return $r(t)$, each term on the right-hand side of this expression can be calculated for each new intangible asset from the data described above, with the capital gain term proxied by the three-year moving average of changes in the non-farm business price

${ }^{22}$ As indicated in Table 1, two components of innovative property (mineral exploration and a portion of architectural design services) are already included in the NIPAs and are not included as intangibles in Table 2; thus, we are implicitly counting them as tangible assets in the growth accounting results that follow. We left them as categorized by the BEA to simplify the presentation; in any case, these categories are small enough that reclassifying them would make little difference in the sources of growth analysis. 
deflator. We include the usual Hall-Jorgenson tax terms in our actual calculations although they are not shown in (6) for simplicity of exposition. We estimate the net rate of return $r(t)$ using the procedure developed in Jorgenson and Griliches (1967) that solves for the common value of $r(t)$ in each year that causes the accounting identity in equation (5) to hold for all types of capital, intangible and tangible. ${ }^{23}$

\subsection{Output Measures and Income Shares}

The next link in completing the data needed for the SOG equation (2e) is the estimation of output and the associated income shares. Following equation (2d), nominal output in the non-farm business sector is the sum of our estimates of current dollar intangible investment, $P^{N}(t) N(t)$, and deliveries of consumption and tangible investment to final demand, $P^{C}(t) C(t)+P^{I}(t) I(t)$. The income shares follow immediately by dividing each element on the right-hand side of $(2 \mathrm{~d})$, $P^{L}(t) L(t), P^{K}(t) K(t)$, and $P^{R}(t) R(t)$, by the value of output. These shares are shown in the last column of Table 2 for the periods 1973-95 and 1995-2003.

To highlight how the accounting differs when intangibles are counted as investment, Table 3 shows the elements of the income identity $P^{Q}(t) Q(t)=$ $P^{L}(t) L(t)+P^{K}(t) K(t)+P^{R}(t) R(t)$, along with the associated shares. As can be seen in the memo items, including all intangibles lowers the labor share of income from about 70 percent to 60 percent and raises the capital share (the sum of lines 12 and 13) from about 30 percent to 40 percent. Note that intangibles account for 37.5 percent of all capital income (line 13 as a share of line 12 plus line 13).

The full time series of the new labor share is provided in Figure 3. The lowering of the labor share is one of the more startling results of the "new view" of intangibles. Not only is labor's share significantly lower when all intangibles are capitalized, the "new" share is no longer constant (as it appeared to be before software was capitalized). Rather, the new share trends downward over the past five decades, particularly since 1980. The growing wedge between the old and new views of labor's share reflects the fact that an increasing fraction of capital income has been associated with intangibles. ${ }^{24}$

To obtain an index of real output growth including the new intangibles, we aggregate the existing real non-farm business output and the real investment series for each of the new categories of intangible assets, $N_{i}(t)$, using a Divisia index

\footnotetext{
${ }^{23}$ It is worth emphasizing that the Jorgenson-Griliches procedure for estimating the rate of return results in a common rate of return to both tangibles and intangibles. This assumes that businesses arbitrage their investments across all types of capital, investing in each type until the rate of return for all assets is equal. While this assumption about investment may be disputed by Schumpeterians, we believe that it is the logical starting point for incorporating intangibles into the sources-of-growth analysis because it treats intangibles symmetrically with the way tangibles are treated in the existing SOG literature. In particular, it is symmetric with the way the official SOG estimates are constructed by the BLS. We also note that we developed these estimates in March 2005, and at that time BLS data only extended through 2002. Following Oliner and Sichel, we use a regression equation to project $r(t)$ for 2003; explanatory variables include two lags of $r(t)$, inflation in the non-farm business sector, the acceleration of real output in the non-farm business sector, the unemployment rate, and the profit share.

${ }^{24}$ This income appears in the first column of Table 3 (and on the income statements of companies in the economy) as retained earnings. Additions to retained earnings translate into a long-run increase in national wealth as corporate share values increase. To the individual investor, it appears as an increase in personal wealth from stocks, pensions, insurance, etc.
} 
TABLE 3

Value of Output and InPuts, Non-Farm Business Sector, 2000-03 (ANNUAL AVERAGE, BILLIONS OF DOLLARS)

\begin{tabular}{lcc}
\hline \hline & $\begin{array}{c}\text { Conventional, Without } \\
\text { Intangibles } \\
\text { Equation (1d) }\end{array}$ & $\begin{array}{c}\text { This Paper, With } \\
\text { Intangibles } \\
\text { Equation (2d) }\end{array}$ \\
\hline 1. Conventional nominal output $\left(P^{C} C+P^{I} I\right)$ & 7,670 & 7,670 \\
2. + Intangible investment $\left(P^{N} N\right)$ & 0 & 1,206 \\
3. = Nominal output & 7,670 & 8,876 \\
4. - Indirect business taxes ${ }^{1}$ & 736 & 736 \\
5. - Statistical discrepancy & -52 & -52 \\
6. = Total income & 6,986 & 8,192 \\
7. Total income & 6,986 & 8,192 \\
8. = Labor compensation $\left(P^{L} L\right)$ & 4,915 & 4,915 \\
9. + Income accruing to tangible capital $\left(P^{K} K\right)^{2}$ & 2,071 & 2,046 \\
10. + Income accruing to intangible capital $\left(P^{R} R\right)$ & 0 & 1,231 \\
Memo: Shares out of total income (percent) & & \\
11. Labor compensation $(8) /(7)$ & 70.4 & 60.0 \\
12. Tangible capital $(9) /(7)$ & 29.6 & 25.0 \\
13. Intangible capital $(10) /(7)$ & & 15.0
\end{tabular}

Notes: The figures in this table are consistent with those used by the BLS in putting together its multifactor productivity estimates for the non-farm business sector. The figures in the first column, however, exclude software, and thus nominal output (line 3) and total income (line 7) are lower by NIPA estimates for software spending by non-farm businesses.

${ }^{1}$ Estimates of indirect business taxes for the non-farm business sector (now known as taxes on production and imports) were inferred, given figures for lines 3,5 , and 6 .

${ }^{2}$ The figure for income accruing to tangible capital in the second column differs from that in the first column because the net rate of return - the term $r(t)$ in equation (6) - changes slightly when intangibles are included.

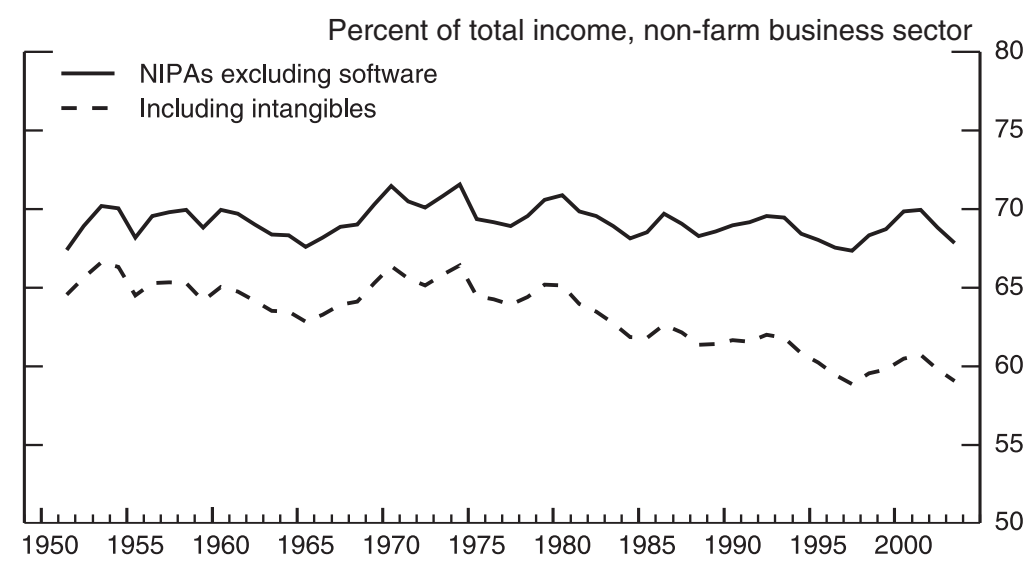

Figure 3. Labor Share

Source: Authors' calculations. 
TABLE 4

Annual Change in Labor Productivity, Non-farm Business Sector

\begin{tabular}{|c|c|c|c|}
\hline & $1973-95$ & $1995-2003$ & $\begin{array}{l}\text { Memo: } \\
\text { Accel. }^{2}\end{array}$ \\
\hline \multicolumn{4}{|l|}{ Published data, excluding software } \\
\hline 1. Labor productivity (percent) ${ }^{1}$ & 1.36 & 2.78 & 1.42 \\
\hline \multicolumn{4}{|l|}{ Contribution of components: ${ }^{2}$} \\
\hline 2. Capital deepening & 0.60 & 0.98 & 0.38 \\
\hline 3. IT equipment & 0.33 & 0.70 & 0.37 \\
\hline 4. Other tangible capital & 0.27 & 0.28 & 0.01 \\
\hline 5. Labor composition & 0.28 & 0.38 & 0.10 \\
\hline 6. Multifactor productivity & 0.48 & 1.42 & 0.94 \\
\hline \multicolumn{4}{|c|}{ Published data, including business investment in intangibles } \\
\hline 1. Labor productivity (percent) ${ }^{1}$ & 1.63 & 3.09 & 1.45 \\
\hline \multicolumn{4}{|l|}{ Contribution of components: ${ }^{2}$} \\
\hline 2. Capital deepening & 0.97 & 1.68 & 0.71 \\
\hline 3. Tangibles & 0.55 & 0.85 & 0.30 \\
\hline 4. IT equipment & 0.30 & 0.60 & 0.30 \\
\hline 5. Other ${ }^{3}$ & 0.25 & 0.24 & -0.01 \\
\hline 6. Intangibles & 0.43 & 0.84 & 0.41 \\
\hline 7. Software & 0.12 & 0.27 & 0.15 \\
\hline 8. Other (new CHS) & 0.31 & 0.57 & 0.26 \\
\hline 10. Labor composition & 0.25 & 0.33 & 0.08 \\
\hline 11. Multifactor productivity & 0.41 & 1.08 & 0.67 \\
\hline
\end{tabular}

Notes:

${ }^{1}$ Output per hour of all persons.

${ }^{2}$ Percentage points. Components may not sum to totals because of independent rounding.

${ }^{3}$ Includes mineral exploration and the architectural and design services embedded in equipment purchases.

procedure. ${ }^{25}$ The result is the growth rate of output $g_{Q}(t)=s_{C}(t) g_{C}(t)+$ $s_{I}(t) g_{I}(t)+\sum_{\mathrm{i}} s_{N i}(t) g_{N i}(t)$. This is the final data series needed to complete the SOG analysis.

\section{Growth Accounting Results}

The estimates of Section 3 provide the elements needed to construct growth accounts with intangibles. We can then compare the SOG models with and without intangibles (equations (1e) and (2e) of Section 2). The SOG results are shown in Table 4 for two periods, 1973-95 and 1995-2003, which were selected in order to analyze the role played by intangible investments in the productivity pickup that is usually dated from 1995 in the recent SOG literature. ${ }^{26}$

The top panel in Table 4 presents the growth accounts based on equation (1e), the SOG without any intangibles. ${ }^{27}$ These results are based on BLS estimates

\footnotetext{
${ }^{25}$ Because nominal business investment for each of the new intangible assets is deflated with the non-farm business deflator, Divisia aggregation and fixed-weight (or simple sum) aggregation yield the same series for real non-farm business output including business investment in intangible assets.

${ }^{26}$ The figures here follow the methodology described above, which also coincides with that used by the BLS to produce their estimates of multifactor productivity growth. For a description of their methodology, see BLS (1983).

${ }^{27}$ The figures in Table 4 and throughout the paper are consistent with the 2004 annual revision of the NIPAs.
} 
of the growth of labor productivity in the non-farm business sector, from which we have excluded software. ${ }^{28}$ The estimates provide the baseline for comparison with SOG estimates based on equation (2e) with intangibles, shown in the bottom panel of Table 4. A number of conclusions can be drawn from a comparison of the two panels. First, it is apparent that the capitalization of intangibles increases the rate of growth of output per hour in both the 1973-95 and 1995-2003 periods. Interestingly, the increase in growth rates relative to the baseline is largest in the earlier period (20 percent) compared with the second (11 percent). However, it is worth noting that the second period covers both the technology boom and the subsequent technology bust. Estimates that refer only to the 1995-2000 period would show a greater influence of intangible investments on labor productivity growth. The dependence of growth accounting estimates on the period of analysis, and particularly on the endpoints, is a well-known characteristic of this type of analysis.

Second, the relative importance of the factors "explaining" growth changes significantly when intangibles are introduced. In the first period, the portion of top-line growth explained by intangibles goes from 0 percent in the top panel (by definition) to 26 percent with them, and the corresponding numbers for the 1995-2003 period are 0 percent and 27 percent, respectively. Moreover, intangibles moved up to parity with tangible capital in its importance as a source of growth during the second period. Put another way, capital plays a larger role in accounting for labor productivity growth once intangibles are included. In the earlier period, capital accounted for 59 percent of labor productivity growth when intangibles are included, but only 44 percent when they are excluded. In the latter period, the difference is even greater, with capital accounting for 54 percent of growth when intangibles are included but only 35 percent when they are excluded.

Third, a comparison of MFP growth rates reveals that this source of growth declines both in absolute and relative importance when intangibles are included as investment. This is most pronounced for the second period, during which the average annual growth rate of MFP drops from 1.42 percentage points under the "old" view to 1.08 percentage points when intangible investments are included in the analysis. Expressed as a fraction of the rate of growth in output per hour, MFP declines in importance from 51 percent to 35 percent. This result is not particularly surprising in light of Jorgenson and Griliches (1967) and in view of the fact that MFP is measured as a residual.

Fourth, one thing that cannot be claimed for the "new" view is that intangibles affected the size of the mid-1990s pickup in labor productivity itself. The third column in both panels shows the percentage-point acceleration in each SOG factor between the two periods. It is apparent that the size of the acceleration in labor productivity in percentage points was virtually the same in both panels.

Fifth, the source of the mid-1990s acceleration in labor productivity does change when intangibles are included. In the top panel, the acceleration in MFP

\footnotetext{
${ }^{28}$ The items listed under the heading "Contribution of Components" are the growth rate of each input weighted by the corresponding income share. In moving from one formulation to the other, we make appropriate adjustments to the income shares. We should note that we prepared these estimates in March 2005, at which time BLS's published estimates extended through 2002. We estimated the year 2003 using procedures developed in Oliner and Sichel (2000, 2002).
} 
TABLE 5

Contribution of Intangible Capital Deepening to the Annual Change in Labor Productivity, Non-Farm Business Sector (PERCENTAGE POINTS)

\begin{tabular}{lccc}
\hline \hline & $\begin{array}{c}\text { 1973-95 } \\
(1)\end{array}$ & $\begin{array}{c}\text { 1995-2003 } \\
(2)\end{array}$ & $\begin{array}{c}\text { Accel. } \\
(3)\end{array}$ \\
\hline 1. Intangible capital deepening & 0.43 & 0.84 & 0.41 \\
2. Computerized information & 0.12 & 0.27 & 0.15 \\
3. Innovative property & 0.13 & 0.22 & 0.09 \\
3a. Scientific & 0.05 & 0.08 & 0.03 \\
3b. Non-scientific & 0.08 & 0.14 & 0.06 \\
4. Economic competencies & 0.17 & 0.35 & 0.18 \\
4a. Brand equity & 0.04 & 0.08 & 0.04 \\
4b. Firm-specific resources & 0.13 & 0.27 & 0.14 \\
\hline
\end{tabular}

Note: Components may not sum to totals because of independent rounding.

accounts for two-thirds of the total pickup when intangibles are excluded, but accounts for less than half in the bottom panel when intangibles are included. Correspondingly, the role of capital in the acceleration of labor productivity is considerably larger when intangibles are included.

In sum, the results shown in Table 4 strongly suggest that intangibles matter not just for national income and wealth accounting, but for growth accounting as well. Indeed, our estimates, rough as they may be, imply that the traditional practice of expensing intangibles results in a seriously distorted picture of the sources of growth.

Table 5 continues the SOG of Table 4 by disaggregating line 6 of that table's lower panel into the separate components shown in Table 1. It is probably not surprising that computerized information (software) is an important factor driving the growth of the total intangible variable in Table 4, but it is perhaps more surprising that firm-specific resources are found to be of equal importance. The rather small role of scientific R\&D also is surprising in light of the attention that R\&D has been given in the literature on innovation. Scientific R\&D accounts for only a modest portion of total intangible capital deepening and is markedly less important than investment in software. ${ }^{29}$ It is also worth noting that the nontraditional types of intangibles highlighted in this paper-non-scientific R\&D, brand equity, and firm-specific resources - together account for nearly 60 percent of total intangible capital deepening since 1995. Because software is already capitalized in the NIPAs, and scientific R\&D will probably be sometime over the next decade, our results suggest that growth accountants should not lose sight of these other forms of intangible capital.

This paper highlights the importance of intangibles as a source of economic growth. However, because software is already included in published growth

\footnotetext{
${ }^{29}$ This result hinges, at least in part, on our assumption that the non-farm business output price is an appropriate deflator for scientific R\&D. If we followed the R\&D literature and used a deflator with a wage component, the result that scientific R\&D played a relatively small role in accounting for recent U.S. economic growth would be, if anything, stronger. On the other hand, if the deflator for IT investment were used instead (as suggested by Mairesse and Kosoglu, 2005), we would find that scientific R\&D played a more important role.
} 
TABLE 6

Annual Change in Labor Productivity, Non-Farm Business SECTOR

\begin{tabular}{|c|c|c|c|}
\hline & $1973-95$ & 1995-2003 & $\begin{array}{l}\text { Memo: } \\
\text { Accel. }\end{array}$ \\
\hline 1. Labor productivity (percent) ${ }^{1}$ & 1.47 & 2.95 & 1.48 \\
\hline Contribution of components: ${ }^{2}$ & & & \\
\hline 2. Capital deepening & 0.73 & 1.26 & 0.53 \\
\hline 3. IT equipment and software & 0.46 & 0.99 & 0.53 \\
\hline 4. Other equip. and structures & 0.27 & 0.27 & 0.00 \\
\hline 5. Labor composition & 0.27 & 0.37 & 0.10 \\
\hline 6. Multifactor productivity & 0.47 & 1.32 & 0.85 \\
\hline $\begin{array}{l}\text { Notes: } \\
{ }^{1} \text { Output per hour of all persor } \\
{ }^{2} \text { Percentage points. Compone } \\
\text { of independent rounding. } \\
\text { Source: Unpublished update } \\
\text { based on data from Bureau of Lal } \\
\text { tivity Trends, } 2002(2004) \text {. }\end{array}$ & $\begin{array}{l}\text { S. } \\
\text { ts may not } \\
\text { o Oliner an } \\
\text { or Statistic }\end{array}$ & $\begin{array}{l}\text { sum to totals } \\
\text { d Sichel (200 } \\
\text {, Multifactor }\end{array}$ & $\begin{array}{l}\text { because } \\
\text { 0, 2002) } \\
\text { Produc- }\end{array}$ \\
\hline
\end{tabular}

accounts, another question is relevant: how much impact would the capitalization of the other intangibles have on published growth rates? Table 6 addresses this question by showing estimates for the non-farm business sector, including software but not the other intangibles, for periods shown in Tables 4 and 5. A comparison of the top-line result in Table 6 with the corresponding estimate on line 1 in the lower panel of Table 4 indicates that the growth rate of output per hour is not greatly increased by the inclusion of the other intangibles from 1995-2003 (2.95 percent versus 3.09 percent). However, the composition of the sources of growth is affected, with a significantly greater role for capital deepening with the full accounting for intangibles and a proportionately smaller role for MFP. Again, the capitalization of intangibles matters for the understanding of U.S. economic growth.

\section{CONCLUSION}

The rapid expansion and application of technological knowledge in its many forms (research and development, capital-embodied technical change, human competency, and the associated firm-specific co-investments) are key features of recent U.S. economic growth. Accounting practice traditionally excludes the intangibles component of this knowledge capital and, according to our estimates, excludes approximately $\$ 1$ trillion from conventionally measured non-farm business sector output by the late 1990s and understates the business capital stock by $\$ 3.6$ trillion. The current practice also overstates labor's share of income by a significant amount and masks a downward trend in that share. Our results also suggest that the inclusion of intangibles both as an input and as an output can have a large impact on our understanding of economic growth. We have found that the inclusion of intangible investment in the real output of the non-farm business sector increases the estimated growth rate of output per hour by 10-20 percent relative to the baseline case which completely ignores intangibles. Thus, the 
inclusion of intangibles matters for labor productivity growth rates, although it has little effect on the acceleration of productivity in the 1990s. On the input side, intangibles reached parity with tangible capital as a source of growth after 1995, and when the two are combined, capital deepening supplants MFP as the principal source of growth. Moreover, the majority of the contribution of intangibles comes from the non-traditional categories of intangibles identified in this paper.

It is also worth noting that the fraction of output growth per hour attributable to the old "bricks and mortar" forms of capital investment (labeled "other tangible" capital in the lower panel of Table 4) is very small, accounting for less than 8 percent of the total growth in the period 1995-2003. While it is inappropriate to automatically attribute the other 92 percent to "knowledge capital" or "the knowledge economy," it is equally inappropriate to ignore the association between innovation, human capital, and knowledge acquisition, on the one hand, and investments in intangibles, IT capital, labor quality change, and multifactor productivity, on the other.

That intangibles, and more generally, knowledge capital should be such an important driver of modern economic growth is hardly surprising, given the evidence from everyday life and the results of basic intertemporal economic theory. What is surprising is that intangibles have been ignored for so long, and that they continue to be ignored in financial accounting practice at the firm level. The results presented this paper are intended to illustrate the potential magnitude of the bias arising when they are excluded from economic growth accounting. In the process, we have been forced to make a host of assumptions about many empirical issues, in order to measure such items as output deflators and non-market inputs like firmspecific organization and human competencies. Further research will undoubtedly find better ways to deal with these issues, and future data collection efforts will evolve to fill the gaps that this paper only traverses lightly. However, while our results are clearly provisional, we are also mindful of the famous dictum of John Maynard Keynes that it is better to be imprecisely right than precisely wrong.

\section{REFERENCES}

Abowd, John M., John Haltiwanger, Ron Jarmin, Julia Lane, Paul Lengermann, Kristin McCue, Kevin McKinney, and Kristen Sandusky, "The Relation among Human Capital, Productivity, and Market Value: Building Up from Micro Evidence," in C. Corrado, J. Haltiwanger, and D. Sichel (eds), Measuring Capital in the New Economy, Studies in Income and Wealth, Vol. 65, University of Chicago Press, Chicago, 2005.

Ayanian, Robert, "The Advertising Capital Controversy," Journal of Business, 56, 349-64, 1983.

Baily, Martin Neil, "Productivity and the Services of Capital and Labor," Brookings Papers on Economic Activity, 1, 1-65, 1981.

Bartel, Ann, "Employee Training Programs in U.S. Businesses," in David Stern and Josef Ritzen (eds), Market Failure in Training: New Economic Analysis and Evidence on Training of Adult Employees, Springer-Verlag, 1991.

- "Productivity Gains from the Implementation of Employee Training Programs," Industrial Relations, 33, 411-25, 1994.

Bassi, Laurie J., Paul Harrison, Jens Ludwig, and Daniel P. McMurrer, "Human Capital Investments and Firm Performance," Mimeo, Human Capital Dynamics, Washington, DC, 2001.

Basu, Susanto, John G. Fernald, Nicholas Oulton, and Sylaja Srinivasan, "The Case of the Missing Productivity Growth, or Does Information Technology Explain Why Productivity Accelerated in the United States But Not in the United Kingdom?" in Mark Gertler and Kenneth Rogoff (eds), NBER Macroeconomics Annual 2003, MIT Press, 9-63, 2004. 
Bernstein, Jeffrey, I. and Theofanis P. Mamuneas, "R\&D Depreciation, Stocks, User Costs and Productivity Growth for U.S. R\&D Intensive Industries," Structural Change and Economic Dynamics, 17, 70-98, 2006.

Black, Sandra and Lisa M. Lynch, "Human Capital Investments and Productivity," American Economic Review, 86, 263-7, 1996.

Bloom, Nick, and John Van Reenen, "Measuring and Explaining Management Practices Across Firms and Countries," Quarterly Journal of Economics, 122, 1351-408, 2007.

Brynjolfsson, Erik and Shinkyu Yang, "The Intangible Costs and Benefits of Computer Investments: Evidence from the Financial Markets," Proceedings of the International Conference on Information Systems, Atlanta, GA, 1999.

Brynjolfsson, Erik, Lorin M. Hitt, and Shinkyu Yang, "Intangible Assets: Computers and Organizational Capital," Brookings Papers on Economic Activity, 1, 137-98, 2002.

Bureau of Labor Statistics, Trends in Multifactor Productivity, Bulletin 2178, September 1983.

Cockburn, Iain and Zvi Griliches, "Industry Effects and Appropriability Measures in the Stock Market's Valuation of R\&D and Patents," American Economic Review, 78, 419-23, 1988.

Comanor, William and Thomas Wilson, Advertising and Market Power, Harvard University Press, Cambridge, MA, 1974.

Corrado, Carol and Larry Slifman, "A Decomposition of Productivity and Costs," American Economic Review, 89, 328-32, 1999.

Corrado, Carol, Charles Hulten, and Daniel Sichel, "Measuring Capital and Technology: An Expanded Framework," in C. Corrado, J. Haltiwanger, and D. Sichel (eds), Measuring Capital in the New Economy, Studies in Income and Wealth, Vol. 65, University of Chicago Press, Chicago, 2005.

Fraumeni, Barbara M. and Sumiye Okubo, "R\&D in the National Income and Product Accounts: A First Look at its Effect on GDP," in C. Corrado, J. Haltiwanger, and D. Sichel (eds), Measuring Capital in the New Economy, Studies in Income and Wealth, Vol. 65, University of Chicago Press, Chicago, 2005.

Griliches, Zvi, "Market Value, R\&D and Patents," Economic Letters, 7, 183-7, 1981. (ed.), R\&D, Patents, and Productivity, University of Chicago Press, Chicago, 1984.

Grimm, Bruce, Brent Moulton, and David Wasshausen, "Information Processing Equipment and Software in the National Accounts," in C. Corrado, J. Haltiwanger, and D. Sichel (eds), Measuring Capital in the New Economy, Studies in Income and Wealth, Vol. 65, University of Chicago Press, Chicago, 2005.

Gullickson, William and Michael J. Harper, "Possible Measurement Bias in Aggregate Productivity Growth," Monthly Labor Review, 122, February, 47-67, 1999.

Hall, Bronwyn H., "The Stock Market Value of R\&D Investment During the 1980s," American Economic Review, 83, 259-64, 1993.

Hall, Bronwyn H. and Robert E. Hall, "The Value and Performance of U.S. Corporations," Brookings Papers on Economic Activity, 1, 1-34, 1993.

Hall, Robert E., "e-Capital: The Link between the Stock Market and the Labor Market in the 1990s," Brookings Papers on Economic Activity, 2, 73-118, 2000.

- "Struggling to Understand the Stock Market," American Economic Review Papers and Proceedings, 91, May, 1-11, 2001a.

- "The Stock Market and Capital Accumulation," American Economic Review, 91, 1185-202, 2001b.

Hall, Robert E. and Dale W. Jorgenson, "Tax Policy and Investment Behavior," American Economic Review, 57, 391-414, 1967.

Hausman, Jerry, "Cellular Telephone, New Products, and the CPI," Journal of Business \& Economics Statistics, 17, 188-94, 1999.

Hulten, Charles R., "On the 'Importance' of Productivity Change," American Economic Review, 69, 126-36, 1979.

- "Total Factor Productivity: A Short Biography," in New Developments in Productivity Analysis, Studies in Income and Wealth, Volume 65, University of Chicago Press, Chicago, 2001.

Hulten, Charles R. and Frank C. Wykoff, "The Estimation of Economic Depreciation Using Vintage Asset Prices," Journal of Econometrics, 15, 367-96, 1981.

Jaffe, Sidney A., "A Price Index for Deflation of Academic R\&D Expenditures," NSF Working Paper No. 72-310, National Science Foundation, Washington, DC, 1972.

Jorgenson, Dale W., "Capital Theory and Investment Behavior," American Economic Review, 53, 247-59, 1963.

— . "The Embodiment Hypothesis," Journal of Political Economy, 74, 1-17, 1966.

Jorgenson, Dale W. and Zvi Griliches, "The Explanation of Productivity Change," Review of Economic Studies, 34, 349-83, 1967. 
Jorgenson, Dale W. and Kevin J. Stiroh, "Raising the Speed Limit: U.S. Economic Growth in the Information Age," Brookings Papers on Economic Activity, 1, 125-211, 2000.

Jorgenson, Dale W., Mun S. Ho, and Kevin J. Stiroh, "Projecting Productivity Growth: Lessons from the U.S. Growth Resurgence," Atlanta Fed Economic Review, Third Quarter, 1-14, 2002.

Khan, Mosahid, "Investment in Knowledge," STI Review, 42, 19-48, 2001.

Landes, Elisabeth M. and Andrew M. Rosenfield, "The Durability of Advertising Revisited," Journal of Industrial Economics, 42, 263-76, 1994.

Lev, Baruch, Intangibles: Management, Measurement, and Reporting, Brookings Institution, Washington, DC, 2001.

Lucas, Robert E. Jr, “On the Mechanics of Economic Development,” Journal of Monetary Economics, 22, 3-42, 1988.

Mairesse, Jacques and Yusuf Kosoglu, "Issues in Measuring Knowledge: The Contribution of R\&D and ICT to Growth," presented at Advancing Knowledge and Knowledge Economies Conference at the National Academies, Washington, DC, January 10-11, 2005.

McGrattan, Ellen and Edward C. Prescott, "Is the Stock Market Overvalued?" Quarterly Review, Federal Reserve Bank of Minneapolis, 24(4), 20-40, 2000. , "Why did U.S. Market Hours Boom in the 1990s?" Federal Reserve Bank of Minneapolis Research Department Staff Report 369, February 2006.

Nadiri, M. Ishaq and Ingmar R. Prucha, "Estimation of the Depreciation Rate of Physical and R\&D Capital in the U.S. Total Manufacturing Sector," Economic Inquiry, XXXIV, January, 43-56, 1996.

Nakamura, Leonard, "Intangibles: What Put the New in the New Economy?" Business Review, Federal Reserve Bank of Philadelphia, July/August, 3-16, 1999.

- "What is the US Gross Investment in Intangibles? (At Least) One Trillion Dollars a Year!" Federal Reserve Bank of Philadelphia Working Paper No. 01-15, 2001.

, "The Rise in Gross Private Investment in Intangible Assets Since 1978," Mimeo, Federal Reserve Bank of Philadelphia, 2003.

Nordhaus, William D. "Do Real Output and Real Wage Measures Capture Reality? The History of Light Suggests Not," in Timothy F. Bresnahan and Robert J. Gordon (eds), The Economics of New Goods, Studies in Income and Wealth, Vol. 58, University of Chicago Press, Chicago, 1997.

OECD Secretariat, "Measuring Intangible Investment: Selected Bibliography," OECD, 1998 (http:// www1.oecd.org/dsti/sti/industry/indcomp/prod/paper16.pdf).

Oliner, Stephen D. and Daniel E. Sichel, "The Resurgence of Growth in the Late 1990s: Is Information Technology the Story?” Journal of Economic Perspectives, 14, Fall, 3-22, 2000. , "Information Technology and Productivity: Where are We Now and Where are We Going?" Atlanta Fed Economic Review, Third Quarter, 15-44, 2002.

Pakes, A. and M. Schankerman, "The Rate of Obsolescence of Knowledge, Research Gestation Lags, and the Private Rate of Return to Research Resources," Working Paper No. 78-13, C.V. Starr Center for Applied Economics, New York University, 1978.

- "Estimates of the Value of Patent Rights in European Countries during the Post-1950 Period," Economic Journal, 96, 1052-76, 1986.

Parker, Robert and Bruce Grimm, Recognition of Business and Government Expenditures for Software as Investment: Methodology and Quantitative Impacts, 1959-98, Bureau of Economic Analysis, 1999.

Romer, Paul M., "Increasing Returns and Long-Run Growth," Journal of Political Economy, 94, 1002-37, 1986.

Solow, Robert M., "Technical Change and the Aggregate Production Function," Review of Economics and Statistics, 39, 312-20, 1957.

_- "Book Review," New York Times, p. 36, July 12, 1987.

Stiroh, Kevin J., "Computers, Productivity, and Input Substitution,” Economic Inquiry, 36, 175-91, 1998.

— , "Information Technology and the U.S. Productivity Revival: What Do the Industry Data Say?" American Economic Review, 92, 1559-76, 2002.

Terleckyj, Nestor, Research and Development: Its Growth and Composition, Studies in Business Economics No. 82, National Industrial Conference Board, New York, 1963.

Triplett, Jack E., "Economic Statistics, the New Economy, and the Productivity Slowdown," Business Economics, 34, April, 13-17, 1999.

Triplett, Jack E. and Barry P. Bosworth, Productivity in the U.S. Services Sector, Brookings Institution Press, Washington, DC, 2004.

United Nations, System of National Accounts 1993, Commission of the European Communities, International Monetary Fund, Organization for Economic Co-operation and Development, United Nations, and World Bank.

Weitzman, Martin L., "On the Welfare Significance of National Product in a Dynamic Economy," Quarterly Journal of Economics, 90, 156-62, 1976. 